\title{
HISTORY OF THE LOCAL NAMES OF CAPE FISH.
}

\author{
By J. D. F. Grlchrist, M.A., B.Sc., Ph.D.,
}

Government Biologist.

(Read November 28, 1900.)

One of the most important factors to be taken into account in any scientific inquiry into the physical and biological conditions to be met with in South Africa, is the existence of two great ocean currents which encounter each other in this region, the one originating in the heated Indian Ocean, and bringing with it the climatic condition and abundance of forms of animal and vegetable life characteristic of more tropical regions, the other coming from the colder Antarctic regions and producing a very different effect on the coasts on which it impinges.

We are familiar with the results of investigation into the meteorological and biological characteristics associated with the land regions under the influence of these currents, but little or no attention has as yet been directed to marine life, which there is reason to believe is even more interesting in this respect.

The various kinds of fish that are found at different localities on the coast is one of the most striking instances of this, and it was while endeavouring to obtain information as to their occurrence, variety, and relative abundance at these places that my attention was directed to the subject we are about to consider.

An unexpected difficulty arose as to the names used at different places by those who supplied the required information, but who quite unwittingly often employed different names to signify the same fish, and as often the same names to signify different fish.

After some personal inquiry and correspondence the various names have been in a measure reduced to order, but the treatment of the subject is by no means exhaustive, and it was only when it proved to be expanding to undue dimensions that it seemed better to give a summary of results which might be a nucleus for further research. 
Apart from the utility of the subject as a means to an end, it may also prove not uninteresting from a philological point of view, if only as in some measure indicating the rich field of investigation open to the philologist in South Africa.

That it will prove interesting and useful to many amateur naturalists. and enthusiastic fishers in South Africa, who have supplied much of the information, I do not doubt.

Before entering into the question of the origin and history of individual names I shall give a list of those which have been procured. They are arranged alphabetically for convenience of reference, but different names for the same fish are grouped together under one of these names (the oldest as in zoological nomenclature) and are followed by the scientific name so far as it can be ascertained. Where the various synonyms occur again in their alphabetic place a reference is merely made to the oldest name. The list is thus not merely a catalogue, but an attempt to identify the various fish to which the names are applied. This has not been an easy matter, and I cannot hope that the result is at all free from possible error.

In many cases I have added in brackets after the name the locality in which it is used, and in others the authority by whom used. Where the name has only been heard and not found in written form, I have spelt it phonetically and added the word voce. These additions, however, are only given in cases where they seem of particular interest.

[For list see end of this paper where it is also used as an index.]

The most striking feature of this list is the mixture of Dutch and English names, the former being predominant. Of the Dutch names there are several for which no English synonym has been found; nor are these confined to the rarer fish which might be known only in Dutch communities, but include such well-known forms as the Snoek. A very few names-only one or two-occur which are apparently neither of Dutch or English origin, but are for this reason all the more interesting as probable relics of the past, for in nomenclature there is as truly a natural selection or the survival of the fittest, as in the arena of animal life. I hope, indeed, to be able to point out some instances in which the process is now going on.

It is well known to the philologist that names form an unwritten history of the vicissitudes through which a country has passed, as well as reflect the character of the people who originate and use themin short, that the human struggle for existence is-dimly it may be, but faithfully-reflected in nomenclature, and it will be found instructive to keep this in view in endeavouring to trace the origin of the individual names. 
In glancing over the list it will be seen that they can be readily arranged in the following groups :-

(A) Borrowed names, including :

1. Names borrowed from known fish more or less resembling the South African forms.

2. Names borrowed from persons, animals, or things resembling in some respects the fish requiring names.

(B) New names, including:

3. Names derived from some striking peculiarity of colour, shape, \&c.

4. Names derived from habitat.

1. Names borrowed from known fish more or less resembling the South African forms.

This is the most obvious origin of the majority of the names, and fortunately the detailed records kept by the early settlers, now made accessible by the labours of Mr. Leibrandt, are available for use in this inquiry.

When, in 1652, the Dutch East Indian Company decided to make the Cape a calling station for ships passing to and from their possessions in the East, they naturally began to turn their attention to the resources of the country. That the fishing industry was not regarded as one of these is apparent from Van Riebeek's complaint that the early settlers "paid more attention to fishing than to the development of the resources of the country." He even took active steps to discourage any development in this direction, doubtless, however, as he feared that other industries, of more immediate importance to his Company, might suffer thereby, for more than once he mentions the abundance of fish almost as if it were a particular grievance.

But Dutchmen are born fishers, and in an early entry in his Journal (April 6, 1652) we are informed that on his arrival at the Cape, to form a permanent settlement, one of the first things he did was to order "Skipper David Coninck to proceed to shore to search for letters, obtain vegetables, and draw the net for some fish." Four days after this, when the erection of the fort was begun, the same skipper set out on a fishing expedition to the Salt River, not without good results, for he returned with " 750 beautiful Steenbraesems, and four other delicate fish of more delicate flavour than any fish in the Fatherland, one looking like a haddock (Shelvisch) and as good and fat."

The name "Steenbraesem " thus promptly given was undoubtedly adopted on account of a resemblance to the "Brasem" (Cyprimus brama) of Holland, though generically and specifically a different fish. The name has survived to this day under the somewhat modified 
form of "Steenbras," one of the most familiar names at the Cape. It is called Steenbras, White Steenbras, Kaapsche Blaauwe Steenbras. This last name, which I give on the authority of Pappe, does not seem to be now in popular use. Curiously enough the same fish seems to be known at Mossel Bay and Knysna as Vorkbek, or Varkebek, evidently corruptions of Vark-bek, literally Pig-nose. It may be that the Dutch who had spread to these places, not being of the seafaring class, or having lost their recollection of the fish of the fatherland, had invented this new name on account of the resemblance of the snout of this fish to that of a pig, and probably also on account of its habit of grubbing in the mud. If this is so the name throws an interesting side-light on the progress of early colonisation.

As regards the fish that looked like a Haddock, I am at a loss to know to what this could refer, and it is interesting to note that the name has not survived. It may have been a small Geelbek or Kabeljauw.

Van Riebeek's enthusiasm as to the superiority of the flavour of Cape fish has also not survived. Perhaps it is to be regarded as a tinge of the exaggeration and romance of those early voyagers to whom the world was then only becoming known.

The following entry is found at a later date (July 24th): "Stock fish supply exhausted-resolved to catch fresh fish to be supplied 3 times a day as long as the heavy work lasts. Went out fishing yesterday; caught 400 Steenbraesem and about 2,000 Harders, which we salted. Would that fresh meat were so abundant!" Harders are here mentioned for the first time, and the name applied to a South African fish which closely resembles the Dutch "Harder" (Mugil chelo) or English "Grey Mullet" (Mugil capito). The Dutch name Harder has survived in the Colony, and I know of no locality where the English name is used.

The mention of Stock fish is of interest. It occurs again in an entry in the Journal of October 21, 1655, and the context clearly shows that reference is made to the preserved fish brought out from Holland and not to the fish now known as Stok-visch at the Cape. The term is used in Holland with two different significations: (1) As dried Cod, called in Holland Kabeljaauw (Gadus morrhua) in opposition to salted Cod called "Laberdaan"; (2) as the popular name for Merlucius vulgaris known as "Hake" in England, and now known in South Africa, where the same fish occurs, as the Stokvisch, or Stock-fish.

In no instance can I discover that Van Riebeek refers to the South African fish under this name, and in this I am confirmed by Mr. Leibrandt, who is of opinion that this may be explained by 
the absence of the fish itself from South African waters in those days.

It is not mentioned by Kolbe, 1731, nor by Barrow, 1806, but appears in Pappe's list, 1853, with the following note: "It is remarkable that this fish, a notorious denizen of European Seas, was utterly unknown at the Cape of Good Hope before the earthquake of 1809 (December 4th). At first it was scarce and sold at exorbitant prices (4s. 6d.). Since that period it has yearly increased in numbers, and is now a standard fish on the market, being caught in great abundance."

This, however, may be received with a certain amount of reservation till more evidence is forthcoming.

We may note here the derivation of a word used in the Colony having the same double meaning as Stok-visch. It is "Bokkum," signifying in the Colony a small Harder, or Mullet, but also any small fish preserved whole. It is without doubt a corruption of the word " bokking" used in Holland, to signify smoked Herring--the small kind caught late in the year in the Zuider Zee being used for this purpose.

Gadus morrhua (called in Holland the Kabeljaauw, in England the Cod) does not occur in South Africa, but the names have been taken over to designate another fish which occurs in Europe, and is known in Holland as the Omber-visch, in England as the Meagre. This may be made clear by the following table :-

\begin{tabular}{|c|c|c|c|c|}
\hline \multirow{3}{*}{ Europe } & \multicolumn{2}{|c|}{ Merlucius vulgaris } & \multicolumn{2}{|c|}{ Gadus morrhua. Scicena aquila } \\
\hline & $\int(\mathrm{Ho}$ & Stok-visch* & Kabeljaauw & Omber-visch \\
\hline & i (England) & Hake & Cod & Meagre \\
\hline South & & $\begin{array}{l}\text { Stok-visch } \\
\text { or Hake }\end{array}$ & Absent & $\begin{array}{l}\text { Kabeljaauw } \\
\text { or Cape Cod }\end{array}$ \\
\hline
\end{tabular}

It will be seen from this that the identity of Merlucius vulgaris with the northern form was recognised by both the Dutch and English, but not that of Sciana aquila, which received the popular name given to Gadus morrhua in Europe (Kabeljaauw), the reason no doubt being that it is a somewhat rare fish in Holland and England though abundant in South Africa, and, curiously enough, common in the Mediterranean.

This fish was most probably the Cape Cod, well known to English seamen of early days as affording a welcome change of food on the long journey by the Cape to India. In the repertoire of wonderful stories of many an old sea captain is a more or less exaggerated account of the abundance of "Cape Cod" on the Agulhas Bank.

* Dried Kabeljauw and dried Stok-visch also called in Holland Stok-visch. 
It was one of their many superstitions-in this case a very rational one-that it was unlucky to proceed with the voyage without stopping for a time in this locality.

The name Cape Cod is not used in the Colony, where the fish is universally known as Kabeljaauw.

Coming back again to earlier history we find the first mention of the now well-known Snoek in the account of an expedition to Saldanha Bay towards the end of the first year of the settlement at the Cape. The expedition was chiefly in search of seals, but numerous "Harders" and "Steenbraesem" were caught, and "some small sea Snoek." The name thus given has been retained ever since, and is one of the few for which there are no Dutch or English synonyms.

The name "Snoek" in Holland is applied to a fresh-water fish (Esox lucius, the English "Pike"), while the African fish (Thyrsites atun) is essentially a marine form though somewhat resembling the former.

The early settlers seem to have had some hesitation, therefore, in identifying the two fish, for it is called a "sea Snoek." Later generations have been less scrupulous, and it is now known simply as Snoek. The English word Pike does not seem to have been used at all to designate this fish.

It is of interest to note that Thyrsites atun occurs also in New Zealand and South Australia, where it is called the Barracouda, a name which also rightly belongs to another fish (Sphyrana).

The anglicised form Snook is frequently used in the Colony, and it occurs elsewhere (e.g., in Jamaica) as the name of an entirely different fish.

On this same voyage to Saldanha Bay we find the first mention of Soles, called in Holland Tongen. They were named Tong, and the name is commonly used amongst the Colonial fishermen of the present day, though it seems to be in the process of being replaced by the English " Sole."

A characteristic of the early Dutch settlers comes out strongly in the naming of the animals and things they found in the new country. They were men of action with little time or inclination for reflection or scientific interest in things in themselves. For utilitarian purposes if a Dutch name could be got for a fish having some resemblance, however remote, to those already known they promptly applied the European name. When they came across fish totally unlike any known forms they were content to call them strange fish, or they might, by way of more definite specification, add some statement as to their taste when cooked. Thus in an account 
of an expedition to St. Helena Bay the entry occurs in the Journal: "Boat caught about 100 strange fish-not nice;" and again on another occasion they "caught some sweetly tasting fish," and "caught some fish (name unknown)."

But even the most stolid anti-scientific Philistine will on occasion become enthusiastic over the wonders of nature. At St. Helena Bay we are told some specimens of a remarkable fish were caught, which had " an antiquated head, a sharp spear on the back, and a tail like a shark; some had small legs, which they could draw up under the stomach, very strange-as may be seen from the accompanying sketch." This was apparently "Callorynchus antarcticus," the "small legs" being the "claspers" of the male. The investigations of the Dutch skipper have been followed up, and the fish has proved even more wonderful than he imagined. No name was given then to the fish, but it is now known as "Joseph, or Josup," a name the origin of which is as puzzling as the fish itself. I have not seen the name printed or written, and so far can suggest no plausible derivation. It may be a corruption of "Jood's visch" or "Jew's fish."

It is somewhat striking that the early Dutch seamen seem to have found many fish which are not now known to occur in the Colony, and of which the names have not survived. Thus we are informed that "Soles (Tongen), Plaice (Schol) Flounders (Bot), and other flat fish as well as Haddock (Shelvis)" were found at Saldanha Bay. Of these the present Dutch fishermen at that place know only the Sole.

A similar instance of the occurrence of varieties of fish not now known we meet with in a later entry. In an expedition to the interior, led by Surgeon Pieter van Meerhoff, we are told by him that in the space of $1 \frac{1}{2}$ hours they caught " beautiful Carp (Kerper)," as much as they could carry away. This is undoubtedly the fish (Spirobranchus capensis) still called Karper in the Colony by the Dutch (in Holland Karper = Cyprmus carpio). When, however, he proceeds to inform us that he also found in the same river " a living monster with three heads like three cats' heads" and provided with "three long tails showing above the water," we come to another instance of an extinct fish which has not left even a name behind.

There appears, therefore, to have been extensive changes in the fauna of our seas and rivers. Even as late as 1731 Kolbe informs us that there was "great plenty and variety of fish in the rivers," where now, alas! they are conspicuous by their absence. He also saw a sea monster, described it in detail, and gave it a name- "Sea Lion." That this is not another name for what is now known as 
the Robbe, or Seal, is apparent from his description, which is as follows :-

"I never saw a Sea Lion but once, and that was at the Cape in the year 1707. A Sea Lion that year came into Table Bay, and having sported for some time in the Bay got upon a cliff and lay there basking in the sun just on the edge of the water. The Cape Europeans had their eyes upon him immediately, and the Governor was quickly informed of this visitor. It was then ebb water. But it was not thought proper to attack him till the water should be fallen a good way from him. When the water had left him some considerable way the Governor ordered out the schallop with three men and as many firearms loaded with bullets to kill this creature. And the schallop coming pretty near him before he stirred, the men fired and despatched him. He was about 15 feet long and as many in circumference. His head was pretty much like that of a lion, save that he had no hair upon it. The tongue was all fat in a manner, and weighed $50 \mathrm{lbs}$. weight. There was neither hair nor scale upon any part of him. The colour of the skin was yellowish. He had forward two short legs ending with feet like those of a goose. These, I suppose, were of great advantage to him in swimming. In the place of hind legs he had two broad thick fins, each 18 inches long. His body tapered to the tail, which ended in the shape of a half-moon."

It is difficult to account for these lost names, and we cannot but reflect on the proverbial veracity of early travellers, in general and of fishers of all times in particular.

It cannot, however, be inferred that they were more lacking in knowledge or observation than their present-day successors, and we may quote an instance to show this. In an expedition, October 20, 1657, " on the upper side of the Diamond and Paarl Mountain, following the course of the river" (evidently the Berg River), the explorers "caught some fish called Barmer and of pleasant flavour, rather full of bones though, like the Dutch Pike." The word Barm, or Barbeel, was evidently brought from Holland, where Barbeel or Berm is used for Barbus vulgaris, also called in Britain the Barbel. The fish found in the Berg River was doubtless also a Barbel, viz., Barbus capensis, which is known to occur there at the present day. It is now, however, called by the Dutch "Moggel" - a word which, as has been suggested (Mr. Tooke), may be a corruption of the Latin Mugil, a generic name which has been applied to this fish, or it may refer to the general appearance and shape of this fish, "moggel" in Dutch signifying a clumsy child. Quite recently inquiries were made as to 
whether this fish was a trout, and it was suggested that it might be a cross between a springer and a trout, as it had not been observed till recently.

Again as to their powers of observation, we find mention made in 1649 of the occurrence of Herring in the waters of the Colony. More than two hundred years later no little excitement was caused in the Colony by the discovery of "true Herring" at Port Alfred.

These fish are properly called Herring, and are a species peculiar to the Cape (Clupea ocellata), differing little from the European Herring (Clupea harengus). As evidence of the slow progress or even retrogression of popular scientific knowledge we may note that they are now generally known as "Sardyn," and if further evidence is wanted we find that the Harder, or Mullet, is now not unfrequently called the Cape Herring.

They are mentioned by Kolbe (1731) who tells us that "in the Cape seas there are shoals of Herring agreeing in every particular with the European Herring, and there is likewise about the Cape a sort of Herring the Cape Europeans call Harters." This is inaccurate, but not so inaccurate as the present-day popular nomenclature.

A few other names, obviously borrowed from European fishthough I have not been able to find any historical references-are the Elf (Temnodon. saltator), which somewhat resembles the Elft (Clupea alosa) of Holland, though the two are by no means scientifically related; the Gurnard, or Knorhaan (Trigla peronii), not unlike its European representative (Trigla gurnardus); the Maasbanker, which is identical with the Maasbanker (Caranx trachurus) of Holland, and indeed is to be found almost everywhere within the temperate and tropical zones of both hemispheres. The English name for this fish (Horse Mackerel) is seldom heard in the Colony. Like the emphatic word "Snoek" it has retained its place, and, like it, is also represented in the New World by a modified form, "Mossbonker." It is otherwise with its kinsman the "Makreel," which seems to be giving place to the English form "Mackerel." The Cape Mackerel (Scomber grex) is closely allied to the northern form (Scomber scomber), both belonging to a family of very wide distribution. Another name obviously borrowed is that of the Cape Pijl Staart (Myliobatis aquila and Trygon pastinaca) from the fish of that name in Holland (Trygon pastinaca). The word Spiering, used in Holland as the popular name for Salmo eperlanus (the English Smelt) is also found in the Colony, and is applied to a fish somewhat resembling it (Atherina breviceps), but quite different scientifically. It is also called Spieringtje at Hout Bay and 
Somerset Strand, and Castelnau says Cape fishermen also call it Assance. The Rog, or Roch, of Holland, Skate of England, is closely related to the Cape form (Raja maculata), and the word Vleet, used in Saldanha Bay, is most probably the name of a fish resembling the Vleet (Raja batis) of Holland, though it has not been described nor have I seen it.

We have commenced this section of names borrowed from Europe with Dutch names, we may fittingly close it by considering a pre-eminently English name.

If the tiger of the sluggish rivers of Holland, the Snoek, or Pike, was prominently in the minds of the Dutch when naming the fish of the new land, it might be expected that the lordly Salmon would be readily suggested to the British by any form at all resembling it. I have been informed (Mr. Thompson) that the name Cape Salmon has been applied to the commonplace Kabeljauw, and even to the culinary-looking Stock-fish, but it is now appropriated almost exclusively by the Geelbek, a fish which, seen fresh from its native element, certainly does call to mind the brilliance and majestic proportions of its European namesake.

Unlike the name Snoek, however, "Cape Salmon" had a rival already in possession- "Geelbek," and, moreover, its patrons were not undivided. Another fish was found on the East Coast at Port Elizabeth, which presented additional claims to the name, resembling the Salmon not only in shape and colour, but in sporting qualities, and showing almost as much game and fight on the rod as the monarch of mountain streams. It may be true that according to scientists it is only a large kind of Herring (Elops saurus), and it is even indifferent eating, but the towns of the Eastern Province stick to the name, and no little confusion is caused thereby. Thus one of my correspondents at Knysna informed me that the Cape Salmon there was very rare, another that it was very abundant; the explanation being that they were each referring to different claimants to the name.

We can leave the litigants to future generations, who will probably decide in favour of the Herring with the sporting qualities, which has besides no other name of its own. The Stock-fish and Kabeljaauw may retire from the contest, though we need not grudge the little glory which the latter still retains in the remote little village of Paternoster on the West Coast (see List).

We have now exhausted the list of names borrowed from Dutch or English fish, and have to mention two which have been adopted from the vocabulary of the cosmopolitan sailor. These are the Bonito (Thynnus pelamys), probably the Barneta of Britannia 
Bay, and the Albacore-a name applied by seafaring men to other species of this genus, but which has been appropriated in South Africa by quite a different member of the Mackerel tribe, viz., Seriola lalandii. This seems quite unnecessary, as it is already provided with a well-known name, "Yellow tail"-Dutch "Geelstaart." As if this were not enough, it has also an extraordinary number of corruptions or variations of the name, viz., Albukure (Valentyn), Alfakoor (Cape Town), Albert-Koord (Hoetje's Bay), and Halfcord (Pappe). After this we are not surprised to find the same fish reported from Australia under the alias of " King Fish."

Two other names remain to be mentioned in this category if I am right in their derivations. These are the Leer-visch and the Panga.

As to the former the word Leer is evidently the Dutch leer or leder (English leather). I cannot find that any fish bears this name in Holland, but a passage in Valentyn's account of the Fishes of the East Indies (1726) seems to throw some light on the subject. He describes (p. 339) a fish resembling our Leer-fish (Lichia amia) and which he calls by this name on account of its "thick brown skin, almost like leather." Probably the Cape Leer-fish was so named by the early Dutch sailors, who brought the name from the East Indies, and were struck with the similarity in the leathery skin of each.

So far as I can ascertain there is not a single name which the Dutch have taken over from the natives of this country. The "Strand Loopers" whom the early settlers found eking out a precarious living by fishing and gathering shell-fish on the shore, and who must have had names for the various marine animals in which they were particularly interested from a practical point of view, have left no historical trace in fish nomenclature, nor have the various tribes of Hottentots, Kaffirs, \&c. However closely the early settlers may have come in contact with the aborigines in commercial relations, there is evidence that in this respect they showed very little assimilative tendency, and we look in vain here for any trace of the presence of the lowly people, whom the Dutch found in possession of the land. It might have been expected that the Malay slaves whom the Dutch brought from their possessions in the East would have retained some of their native names, more especially as they soon became pre-eminently the fishing section of the community. I have found, however, only one name which can with any probability be traced to such an origin. This is the name "Panga" (Pagrus laniarius). The fish to which this name is applied bears a strong resemblance to the common Silver-fish, and at 
many places in the Colony does not seem to be distinguished from it by any specific name. It differs, however, from this fish in having a slightly different shape and in having two of the front teeth somewhat protruding from the mouth. As the name is chiefly used by the Malay fishermen, and no other derivation has been suggested, it seems probable that it may have been originally a Malay name; and there is some confirmation of this. Valentyn in his "Old and New East Indies" mentions a fish which the natives called Ikan Pangerang or Pangarang (literally, prince) which seems to bear some resemblance to the Cape Panga, more especially in its having the protruding teeth. I have some confidence, therefore, in offering this explanation of the name.

An interesting analogous derivation is to be found in the name "Snapper," applied in East London to the Red Stumpnose. This name is applied in Australia to a fish not unlike it, and the origin of the word is doubtless to be found in the English Colonies, just as Panga is to be traced to the early Dutch East Indies.

There seems to be no trace of the early French settlers, except perhaps the name "Carpelle," which I am informed by Mr. Péringuey is sometimes used in Stellenbosch district for the Dutch " Karper" (Spirobranchus capensis).

Summing up, therefore, the names in this section borrowed from known fish we have 23 Dutch, 15 English, 2 Cosmopolitan, 1 Indian, 1 French, and 1 Australian, representing 27 different species. Of these only two are identical with the forms after which they were named. These are the Dutch Stock.fish, (English Hake) and the Dutch Maasbanker (English Horse Mackerel). Another fish, the Dutch Omber-visch (English Maigre), occurred in South Africa, but was not recognised, and the name of another European fish (Kabeljaauw) given to it. The other names were given on account of more or less resemblance to their namesakes.

\section{Names derived from resemblance to persons, animals, or things.}

Wherever the Dutch settlers could find any resemblance, even a remote one, to the fishes of the Fatherland they did not hesitate to apply the known name rather than invent a new one or accept the one already in existence.

It is difficult, however, to discover many such resemblances, and other names had to be found. It is noteworthy that here again the tendency to think of and describe the unfamiliar by the familiar is forcibly illustrated, for the majority of the remaining names are 
derived from known persons, animals, or things, rather than from any outstanding features of the fish themselves.

Thus a certain fish characterised by a large head with striking frontal development, instead of being called Groot Kop, or some such name, is called Bisschop, though Groot Kop would not express that air of ecclesiastical gravity and profundity characteristic of the features of this fish and supposed to be found in a bishop. We may admit that the popular name has, therefore, in this case some claims as against a more strictly scientific designation. But what can one say of the "Fransch Madam"? The fish so called (Chrysophrys holubi) is of a swarthy colour, like the Hottentot Fish, somewhat plump in form and with large black eyes. I do not know if this description applies in any way to a French lady, but probably the inventor of the name detected some points of similitude.

There can, however, be little doubt as to the origin of the name Hottentot, and it requires no great stretch of imagination to see in the fish so called some resemblance to the black, stunted natives whom the Dutch found in possession of the land. Kolbe, however, suggests that the fish was so named because the Dutch were in the habit of purchasing it from the natives, and Nieuhof, because " the Hottentots caught it with a hook." This name is the only one which can be said to be of native origin-and that only very indirectly.

The Fishing-Frog, or Angler of the European seas, is represented in South African waters by a closely allied form (Lophius upsicephalus), and is known in several places in the Colony as the Paddy, and in others as the Devil Fish. In Holland it is known as Kikvorsch Zee-duivel, Hozen-mond or Hozen-bek.

[Note-Miss Wilman, at the meeting of the Society at which this paper was read, suggested that Paddy might be a corruption of Padda, the Dutch for frog. This seems very probable.]

There is at Mossel Bay a somewhat rare fish called the Scotchman, but I have only heard the name, and am unable to say to what species it belongs, or what national characteristic it possesses to justify the designation. It is said to have a very long head.

The Boer Kabeljaauw is a name applied to large Kabeljaauw, a fish which sometimes grows to enormous proportions. Fishermen inform me that it is so called as it is eagerly bought by Dutch farmers who prefer quantity to quality.

The name Mooi Nooije (literally, pretty girl) is not inappropriate to a modest little fish with bright golden stripes which harmonise well with the dark grey and yellow of the sea Bamboo, amongst which it lives. It is for this reason also called the Bamboes-visch. 
The name may be compared with the local name in Holland for young Kabeljaauw, viz., Mooi Meisje, and it is of interest to note that the word "noi" or "nooi" is exclusively a Cape word, probably derived, as Mansvelt suggests, from the Portuguese "noina," meaning a bride.

An allied name is the Kaapsche-Nooije, for which I am unable to suggest any origin.

These names derived from persons have all had a general reference, but there are two which have been named after individuals. The first, commonly called the Seventy-four (Dentex rupestris, Castn.), is also known in some localities as Peter's Fish, on account of its having a black mark on each side of its body such as might have been caused by its being violently seized by some one between the finger and thumb. I have been assured by Dutch fishermen that this is to be connected with the historic incident in which the Apostle Peter so miraculously found the tax-money.

The other case is that of an obscure sailor who has been immortalised in the name Jacopever. Francisci gives a most circumstantial account of the derivation of the name. The Dutch sailor, Jacob Evertsen, was possessed of a peculiar rosy complexion which the historian charitably supposes to have been a congenital not an acquired characteristic. While out fishing one day a remarkable, somewhat comical-looking little fish of a reddish blotched colour and with prominent eyes, was pulled up, and so struck were his mates with the resemblance to their companion that they forthwith christened it "Jacob Evertsen" - a name which it has retained to the present day under the somewhat modified form Jacopever.

As might have been expected, the peculiar fauna of South Africa has furnished some striking names, such as the Zebra, the Dasje, the Elephant, the Porcupine, and the Parrot. The name Zebra-fish, or Wildepaard, is applied to a fish with several wellmarked stripes running across the body. The Dasje might also with a little stretch of the imagination be likened to the rabbit or dassie, from its general shape, and this is the name by which it is known in Cape Town, Hout Bay, and Kalk Bay.

The name Zee-vark (literally, sea-pig) presents some little difficulty, as the fish in no way resembles a pig. The derivation, however, becomes very apparent when we think of the Isser-vark, or Porcupine, and bear in mind that the fish is also called the Porcupine-fish. In the matter of bristles it is even better provided than the Porcupine, and resembles more a hedgehog in its most offensive attitude. The bristles are comparatively long and very sharp, so that the living fish must be handled with care. 
This is the only case of what might be called indirect derivation of a name that I have come across.

Two other names may be compared with it_derived directly from the animal from which they have borrowed the name. These are the Vark-bek, so called on account of its pig-like snout, and the Varkje, so called on account of the grunting noise it makes.

The mane-like dorsal fin of the Paarde-visch, and the horse-like profile of the head, sufficiently accounts for its name, while the hard beak of the Papegaai-visch, or Parrot-fish, called also the Kraai-bek, or Crow-beak, is surprisingly like that of a parrot.

The name Tiger-shark is a libel on the monarch of the jungle. It is applied to a small dog-fish with yellow markings remotely resembling those of a tiger. So far from possessing the proverbial ferocity of his great namesake, this little creature is so shy that when taken out of the water he turns his head away from the onlooker quite abashed-at least, so the Dutch fishermen imagine who have given him for this reason the additional name of Schaam-oog.

The name Bontrok, applied to a species of Dentex at Mossel Bay, appears to refer to its variegated colouring (bonte, variegated, and rok, coat), or is perhaps derived from some supposed resemblance to the Bontrokje, a species of stone-chat.

Coming now to the names derived from inanimate things, we find a most extraordinary miscellany of objects from a man-of-war to a needle.

An anonymous writer in the Cape Monthly Magazine (vol. iv., p. 354) informs us that there was then a tradition that the name of the fish called Seventy-four arose "from its having been caught from a ship of the line of that number of guns on dropping anchor in Simons Bay." Similarly the name Gelleon, applied to a fish in the Dutch East Indies, is stated by Valentyn ("Old and New East Indies," vol. iii.) to have been so called because it followed the ships and was often found about the Galleons ("de Galleonen"). The Cape fish Galleon, or Galjoen, probably got its name in this way though it seems to be different from the East Indian form.

These derivations may be correct, but another naturally suggests itself to those familiar with the appearance of these fish. The Seventy-four is characterised by several very distinct bright blue bands running along the body, not unlike the rows of guns of an ancient man-of-war, one carrying seventy-four guns being considered a well-equipped vessel in those days. The Galjoen also can readily be supposed to have derived its name from its resemblance in shape to the high built three-decker of the fifteenth and sixteenth century called by the Spanish, "Galeon" (Latin, Galea), and by the Dutch "Galjoen" or "Galleon." 
Additional evidence that the Seventy-four derived its name from a Simons Bay warship, is afforded by the fact that on the East Coast (Port Elizabeth and East London) the fish is not so named but is called the Silver-fish.

The Naald-visch, or Needle-fish, is the possessor of a long, slender beak, about half the length of its body - a prolongation of the lower jaw. The name Zee-naald is used in Holland to designate other fish, viz., the Garfish and a species of Syngnathus, but not with the same fitness as in the case of the South African form, and I am inclined to think that the name was not applied here on account of any resemblance to the European fish. This is borne out by the fact that a species of Syngnathus differing very little from that found in Holland occurs in the Colony.

The Melk-visch is said to derive its name from the colour of the flesh when cooked. It may, however, also be from the milk-white colour of the upper part of its mouth.

The Pampelmoes probably derives its name from its resemblance to the fruit so called, a species of bitter lemon. Pappe and Castelnau seem to be wrong in using the name "Pompelmoesje," as a synonym for Steen-klip-visch (Chilodactylus fasciatus).

The Vioel-visch, or Fiddle-fish, is a species of shark with no claim to musical talent, but having a flat body and long tail not unlike the body and neck of a violin.

Windtoy is a name the derivation of which is not very obvious. The spelling “Windtoy" is given by Pappe, Castelnau, and Bleeker, but as pronounced by Malay fishermen sounds more like Wind-ei, which would mean in Dutch a wind-egg, the colour of which is somewhat similar to that of this fish. This derivation I, however, suggest with some hesitation.

Some little difficulty was found in tracing the origin of the word Dageraad, owing to the various corruptions, verbal and written, under which it appears (see List).

I have little hesitation, however, in suggesting that it is the Dutch word Dageraad, meaning dawn of day, or sunrise, and certainly the gorgeous hues of this magnificent fish fully justify the name. The Dutch fisherman who first named the fish must have possessed a poetic imagination of no mean order. The name comes somewhat as a surprise. Rooije, Rooi-man, Rooi-stumpneus we expect, but not Dageraad (day-dawn). Perhaps it may have been a stray flash of oriental fancy not quite extinguished in the humble folks whom the countrymen of Van Riebek brought as slaves from the East.

The name Roman is of special interest. It is maintained by some that the fish takes its name from the Roman Rock in Simons Bay, 
where it is frequently found; by others that the Rock takes its name from the fish. This latter seems to be the most probable derivation, Roman being simply a corruption of Rooi-man. This is apparently lost sight of in the redundancy Red-Roman sometimes heard.

The fish now called Silver-fish is a strikingly red fish, though exhibiting a silvery sheen when fresh. It is so called in Table Bay and False Bay, while in Algoa Bay the name is applied (quite appropriately) to the Seventy-four. The "Gold-fish" described by Kolbe in 1738 seems to be the Cape Town Silver-fish, while his "Silverfish" corresponds well with the present "Zee-basje" of Cape Town. At Port Elizabeth it is not called Silver-fish, but Kapenaar.

Other names derived from colours are the Blue-fish, the Goldstripe-fish, the Keelbek (yellow mouth), the Geel-haai, the Geel-staart already noticed, the Geeloogie (yellow eye), and the Streep-visch.

The John Brown and Jacob Swart stand in a category by themselves. There is no reason to believe that the former is in any way connected with the hero of the American song, or that the latter has any individual reference. The names appear to refer simply to the colour of these fish.

3. Names derived from striking peculiarities of colour, shape, \&c.

We come now to a different class of names. European fish and land animals have been drawn upon for names, but as there is only a limited number of either of these at all resembling South African fish the borrowing process was necessarily a limited one, and new names had to be invented.

Cape fish are, however, particularly adapted to this process. A European, accustomed to the sombre hues of northern forms, is at once struck by the number of fish with bright colours, red being prominent. This is reflected in the names Red Stumpneus, Red Steenbras, Roman (= Roi-man), Rooi-Knorhaan, Roije. The Silverfish, Panga, and Jacopever, are also strikingly red fish, though they have got their names otherwise.

Other names have been derived from various peculiarities, and have only to be mentioned to show their origin. Such are Dikkopje, Dik-bekje, Stompneus, Baardman (from a barbel or feeler under the lower jaw), Haarde-staart, Grunter, Klip Zuiger (from its habit of adhering to rocks), Stink-fish, Springer.

The name Drill-visch is apparently from the Dutch " trillen," to tremble. It is also called the Electric-fish. Both names refer to the unique method of defence or offence possessed by this fish.

One name in this section is of peculiar interest, as it illustrates a 
very primitive method of naming-perhaps the most primitive method of all naming. It is the name Chor-chor, given to a fish which, when caught, makes a grunting noise, apparently imitated in the name. Though not a fish the "Tschokka" may be mentioned as another example of this. It is applied to the Cuttle-fish, or Squid, on account of the peculiar noise it makes when landed.

\section{Names derived from habitat.}

Several names, or parts of names, are derived from the localities in which the fish are found. Thus we have Cape Salmon, Kaapsche Roode Stompneus, Baaische Roode Stumpneus (Pappe) Steenje, Klip Visch, Steen Klip Visch (a peculiar redundancy), Riet Bull, Sand-fish, Sand-Kruiper, and Sand-steenbras.

The name Kaapenaar evidently means Cape Fish. Hangberger is supposed (vide Pappe's Synopsis) to derive its name from Hangberg, a mountain at Hout Bay where the fish occurs, by others from the fact that it frequents overhanging ledges of rock, while I have been informed by a fisherman that it is so called because it is found in deep water off Cape Town at a place which is reached when Hangberg Mountain appears in sight.

We have hitherto considered names for which derivations can be suggested, some with a degree of probability, practically amounting to certainty, others with lesser claim to certainty, and others of very doubtful origin. There are a few, however, for which no plausible derivation can be discovered. These are Bafaro, Assous, Zeverrim, Katonkel, Joseph and its variations, Oortje, Forfarin, Sanchord. The first four have been heard only, and are written down here phonetically, the two following have been obtained from correspondents, and the last appears in Pappe's Synopsis.

The derivations are probably obscured by corruptions of the original words, and I am not without hope that they may be cleared up.

To illustrate how many extraordinary contortions the names may undergo, I give here a list of the corruptions which have been traced to their original forms :-

Albacore corrupted into Albert-Koord (written), Alfacor (heard),

Ansjovi

Biscop
Half-cord (written).

Ansjous (written).

" Poeskop (written), Proenskop (written), Poenskop (heard), Koenskop (heard), Koeskop (heard). 
Dageraad corrupted into Dagara (written), Davaraad (written), Dagerhart (written), Daaga - raad

Jacob Evertsen

Riet Bull , John Brown ,, (written).

Jacopever (heard).
, Red Bull (written).

, Tambrijn (heard).

Having now finished the consideration of the individual names and their derivations, though the subject has been by no means exhausted, we may in conclusion direct attention to a few generalisations which have been forced upon our notice in the course of the inquiry.

It must have been observed that in these names there is a dim shadow of the history of the Colony. The word Hottentot is the only trace of the presence of an aboriginal race, while Panga suggests an East Indian element, and Nooije a Portuguese. The abundance of Dutch words indicates the presence of a more vigorous European people, while the English names, very evidently superimposed upon the Dutch, indicate the arrival of another people.

The old word "Galleon," together with the later "Seventy-four," are suggestive historic remnants, while the much later "Snapper," of Australian origin, brings us up to more recent developments.

An interesting sidelight seems also to be thrown upon the character of these various races. The only aboriginal name, Hottentot, was not taken over by the Dutch as the native name for this fish, but probably, as we have seen, on account of its having a resemblance to, or being in some other way associated with them. I believe there is even some doubt as to this being a native word at all. Similarly another humble people who came in contact with the more vigorous race have left only one single word to suggest their existence.

It is to be noted also that the early French settlers have left no trace of their nationality in these names, unless indeed the "Fransch Madam" and "Carpelle" be regarded as such. The Dutch have, on the other hand, left the impress of their individuality strongly on the nomenclature of the land. We cannot venture, however, to draw any general conclusions in this respect from the limited material we are now utilising, and it is properly a subject for a much wider philological investigation of South African names.

We are on surer ground when we consider names as they are at present distributed in the Colony. The outstanding feature is that those used on the West Coast are mostly Dutch, those on the East Coast English. In fact, there is a striking though accidental 
parallel between the distribution of the various names and that of the fishes themselves.

It has been one of the chief objects of this paper to homologise these names and thus help to eliminate the confusion caused by the application of different names at different places to the same fish, and if this has in a measure been attained we shall be in a better position to secure further information as to the varieties, occurrence, and habits of the fish inhabiting our seas.

This brings us back to the problem with which we started, viz., the distribution of marine forms of animal life and the peculiar. conditions in South Africa which bring this about, and I cannot. but hope that a little clearing up of the confusion of names will help in this investigation, and may induce some who have the opportunity to take an active interest in the subject, and add to our too scantyknowledge of the marine life of South Africa.

\section{LIST OF THE LOCAL NAMES OF CAPE FISH.}

AAL, Paling, Eel ................. Anguilla delalandii.

PAGE:

Albacore, Albicore, Albukur (Valentyn),

Half-cord (Pappe), Alfakoor, voce (Cape

Town), Albert-Koord (Hoetje's Bay),

Yellow-tail, Geel-staart (Struis Bay and

Jeffrey's Bay) $\ldots \ldots \ldots \ldots \ldots \ldots \ldots$. Seriola lalandii ............. 217

Angler. Vide Fishing-Frog.

Ansjovi, Ansjous (Hoetje's Bay), Anchovy,

White Bait (Knysna)?............. Engraulis holodon.

Assance. Vide Spiering.

Assous. Vide Spiering.

BAAR. Vide Barbeel.

Baardman, Baardmannetje (Pappe), Bellman (Riversdale) ................. Umbrina capensis .......... 223

Bafaro, voce (Cape Town) ........... Polyprion prognathus ....... 224

Bamboo-fish. Vide Bamboes-visch.

Bamboes-visch, Bamboo-fish, Stink-fish, Gold-stripe-fish (Hoetje's Bay), Streepje (Knysna), Mooi-nooitje (Hermanuspetrusfontein and Struis Bay) ......... Box salpa

Bank Steenbras (Cape Town). Vide Rooi Steenbras.

Barbeel. Vide Moggel.

Barger (Steenberg's Cove), Baager (Britannia Bay), Baar (Paternoster) ...... Galeichthys feliceps. 
Barm. Vide Moggel.

Barneta. Vide Katonkel.

Barsje (Struis Bay), Zee Basje (Kalk Bay),

Zeverrim, voce (Mossel Bay) ......... Pagellus mormyrus ....... 223, 224

Bastard Galjoen. Vide Papegaai-visch.

Bastard Hottentot, Copper-fish (East

London) ? .................... Sargus capensis.

Bastard Jacopever. Vide also Sancord .. Pimelepterus fuscus.

Bastard Mackerel. Vide Maasbanker.

Bastard-maid (Riversdale and Port Elizabeth........................

Bastard Silver-fish. Vide Silver-fish and Seventy-four.

Bellman. Vide Bardman.

Bijter. Vide Elft.

Biscop, Poeskop, Proenskop (Knysna) ?

Poenskop,Koenskop,\&Koeskop(Mansvelt) Chrysophrys, sp. ........ 219, 224

Black-tail (Mossel Bay) ............. Sargus rondeletii.

Blassop, Toad-fish (E. London) ....... Tetrodon honkenyi.

Blue-fish. Vide Pampelmoes..

Boer Kabeljaauw. Vide Kabeljaauw.

Bokkum. Viảe Harder.

Bonte-haai, Lui-haai, Tiger-shark .... Scyllium africanum ......... 221

Bontrok, voce (Mossel Bay and Knysna) Dentex, sp............... 221

Bruine Knorhaan. Vide Graauwe Knorhaan.

Bull-eye (Cape Town), Bull-eye or Glass-

eye or Bully (E. London) ?.......... Brama raii.

CApe Cod. Vide Kabeljaauw.

Cape Herring. Vide Harder.

Cape Salmon (Cape Town). Vide Geelbek.

Cape Salmon (Port Elizabeth, Kynsna, \&

E. London) $\ldots \ldots \ldots \ldots \ldots \ldots \ldots \ldots$

Cape Salmon (Stompneus and Britannia

Bay). Vide Kabeljaauw.

Carp. Vide Karper.

Carpelle. Vide Karper.

Carpenter. Vide Zilver-visch.

Cat-fish. Vide Platte-kop.

Chor Chor, voce (Mossel Bay), Varkje

(Knysna), Grunter (E. London) Oortje Pristipoma bennettii.......... 224

Copper-fish. Vide Bastard Hottentot.

Dageraad, Dagara (Paternoster)? Davaraad (Struis Bay), Daggerhart (Humans-

dorp), Daga-raad (Kowie), Dagger-head Pagrus laticeps ............ 222

Dasje, Das (Kynsna) ?............. Sargus rondelletii .......... 220

Davaraad. Vide Dageraad.

Devil-fish. Vide Fishing-frog.

Dik-kopje, Dik-bekje Gobius, sp. ............. 22:3

Dog-fish. Vide Vinhaai.

Dolphin. Vide Skipjack. 
Drill-visch (Cape Town), Electric-fish (E.

EeL. Vide Aal.

Electric-fish. Vide Drill-visch.

Elephant-fish. Vide Joseph.

Elf, Shad (Hoetje's Bay), Bijter (= small

Elf) .......................

Temnodon saltator.

Fiddle-fish. Vide Zand Kruiper.

Fishing-Frog, Paddy or Padda (Hout Bay),

Angler, Devil-fish (East London) .... Lophius upsicephalus

Five Fingers. Vide Stompneus.

Flatys (Kowie River) ...............

Flying-fish .................... Exocæetus altipinnis \& longipinnis

Forfarrin (Kalk Bay) $\ldots \ldots \ldots \ldots \ldots \ldots$

Forke Bak. Vide Steenbras.

Fransch Madam

?

Pagrus holubi.

GaLjoen, Galleon, Trek-galjoen (?), Gal-

joen-vis (Mansvelt) ................

Geelbek, Geelbeck (Pappe), Cape Salmon

(Cape Town) ................... Otolithus aquidens.......... 216

Geel-haai (Struis Bay) $\ldots \ldots \ldots \ldots \ldots \ldots . \ldots 223$

Geeloogie (Struis Bay).............. ? $\quad \ldots \ldots \ldots \ldots 223$

Geel-staart. Vide Albacore.

Glass-eye. Vide Bull-eye.

Globe-fish. Vide Zee-vark.

Gold-stripe-fish. Vide Bamboo-fish.

Graauwe or Bruine Knorhaan (Pappe), Knorhaan, Grey Gurnard, Gurnard, Grunter (Riversdale) ..............

Grey Gurnard. Vide Graauwe Knorhaan.

Grunter. Vide Chor Chor, Graauwe, and Roode Knorhaan.

Gurnard. Vide Graauwe and Rhoode Knorhaan.

Hake. Vide Stock-fish.

Halfcord. Vide Albacore.

Hangberger. Vide Hottentot.

Haarde-staart (Struis Bay) ...........

Harder, Mullet, Cape Herring, Bokkum (= Young Harder)

Herring. Vide Sardijn.

Horse-fish. Vide Paarde-visch.

Horse-Mackerel. Vide Maasbanker.

Hottentot, Hottentot fish (Pappe), Rockfish (East London), Hangberger ( = large Hottentot).................. Cantharus blochii

JaCob Swart. Vide Rooi Stompneus.

Jacopever, Jacob Evertsen (Pappe), Jacob Eversson (Kolbe), Karl Grootoog (Struis Bay) 
Jan Bruin, John Brown, Tambrijn ? .... Gymnocrotaphus curvidens ..... 223

John Dory .................... Zeus capensis.

Jaseph, Josvisch, Jusop, voce, Elephantfish ...................... Callorynchus antarcticus.... 213, 224

KaApenaar. Vide Zilver-visch.

Kaapsche Blaauwe Steenbras. Vide Steenbras.

Kaapsche Nooitje (Riversdale \& Knysna). Vide Pampelmoes.

Kabeljaauw, Kabeljouw (Pappe), Cape Cod (English seamen), Wit Kabeljaauw, Kabeljo, voce, Cape Salmon (Britannia Bay), Boer Kabeljaauw (Mossel Bay), and Red-bill or Riet-bull (Knysna)? = large specimens ................. Sciana aquila ......... 210, 219

Kalk-fish, Scabbard-fish ............ Lepidopus argyreus.

Kalverkop (Berg River) ..............

Kapitein-visch ................. Clinus anguillaris.

Karl Grootoog. Vide Jacopever.

Karper, Kerper (Van Riebek's Journal), Carpelle, Carp ................. Spirobranchus capensis ... 213, 218

Katonkel, Katunker.............. Thynnus pelamys ........... 224

Kerper. Vide Karper.

King-klip-fish. Vide Koning-klip-visch.

Klip-visch .................... Clinus, $12 s p . \ldots \ldots \ldots \ldots . .224$

Klip-zuiger, Sucker-fish........... Chorisochismus dentex ....... 223

Knorhaan. Vide Graauwe and Roode Knorhaan.

Koning-klip-visch, King-klip-fish. Vide also Rock Cod ................... Genypterus capensis.

Kraai-bek. Vide Papegaai-visch.

Leaping Mullet. Vide Springer.

Leer-visch, Leather-fish............. Lichia amia 217

Lootsman ..................... Naucrates ductor.

Lui-haai (Smith). Vide Bonto-haai.

MaAn-visch, Sun-fish................ Orthagoriscus mola.

Maasbanker, Bastard Mackerel, Horse

Mackerel..................... Caranx trachurus ........... 215

Makreel, Mackerel ................ Scomber grex ............. 215

Melk-visch ..................... Parascorpis typus ........... 222

Michel. Vide Moggel.

Mooi-nooije. Vide Bamboes-visch.

Moggel (Gouritz River and Berg River), Barbeel or Barm (Van Riebek's Journal), Michel (Knysna) ............... Barbus capensis............. 214

Moon-fish .................... Psettus falciformis.

Mud-fish. Vide Karper.

Mullet. Vide Harder.

Mutton-fish ?

NeEdLE-Fish, Naald-visch.......... Hemiramphus calabareus...... 222 
OontJe. Vide Chorchor

PAGE

PaARde-visch, Horse-fish . ............ Agriopus, $2 s p . \ldots \ldots \ldots \ldots .221$

Paddy. Vide Fishing-Frog.

Pampelmoes, Kaapsche Nooitje, Blue-fish Stromateus microchirus 220, 222, 223

Panga, Panger, Pungas, voce, Roode

Kaapsche Stompneus (Pappe) ? ..... Pagrus laniarius ........... 217

Papegaai-visch, Parrot-fish, Bastard Galjoen (Kalk Bay), Snoek Galjoen (Hoetje's

Bay), Kraai-bek (Knysna) ........... Hoplegnathus conwayi ........ 221

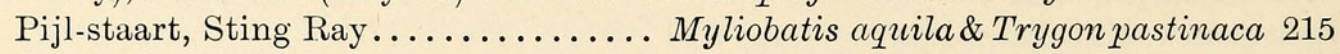

Pipe-fish ..................... Syngnathus acus.

Platte-kop, Catfish ............... Clarias gariepinus.

Poeskop. Vide Biscop \& Rooi Stompneus.

Porcupine-fish. Vide Zee-vark.

Proenskop. Vide Biscop.

Pungas. Vide Panga.

RED-BILL or Riet Bull. Vide Kabeljaauw.

Red Roman. Vide Roman.

Red Steenbras. Vide Rooi Steenbras.

Red Stumpnose. Vide Rooi Stompneus.

River Steenbras. Vide Tiger Fish.

Rock Cod, Koning-klip-visch (Riversdale and Mossel Bay) ................ Epinephehus gigas.

Rock-fish. Vide Hottentot.

Rog, Skate, Spotted Ray............ Raja maculata ............ 216

Roman, Red Roman .............. Chrysophrys cristiceps ........ 222

Roode Knorhaan, Knorhaan, Gurnard .. Trigla capensis.

Rooi Chor Chor, voce (Mossel Bay) ...... Pagellus affinis.

Rooi Steenbras, Roode Steenbrasem (Pappe),Red Steenbrass,Bank Steenbras Dentex rupestris.

Rooi Stompneus, Baaische Roode Stompneus or Poeskop (Bleeker \& Pappe), Red Stumpnose, Jacob Swart (Jeffrey's Bay),

Snapper (East London) ........... Chrysophrys gibbiceps.

Rooitje. Vide Silverfish.

Rooi-vlerk Carper (Smith)........... Barbus burchelli.

Sancord (Pappe), Bastard Jacobpever

(Paternoster) ............................ Sebastes maculatus 224

Sand-fish (Mossel Bay) ........... Dentex filosus ............. 224

Sand-shark (Smith). Vide Zand-kruiper.

Sand Steenbras (Knysna) ..............

Sardijn, Shad, Herring, Sussie (Hout

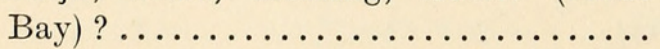

Saw-fish .....................

Scabbard-fish. Vide Kalk-fish.

Scotchman (Mossel Bay)..............

Seventy-four, Silver-fish (Port Elizabeth), Bastard Silver-fish (Pappe), Stripe-fish (Struis Bay), Streep-visch (Swellendam)?

Roode Steenbras (Bleeker)........... Dentex sp. ?

Clupea ocellata

Prisiophorus cirrhatus.

?

Shad. Vide Elft and Sardijn. 
Skate. Vide Rog.

Shipjack (Britannia Bay $=$ Dolphin $?$ Port

Alfred $=$ Cape Salmon $?) \quad \ldots \ldots \ldots \ldots$.

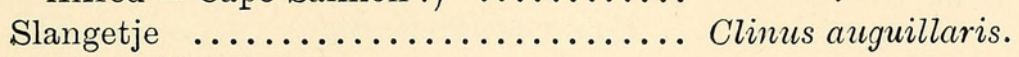

Smelt. Vide Spiering.

Snapper. Vide Rooi Stompneus.

Snoek

Snoek-galjoen. Vide Papegaai-visch.

Sole. Vide Tong.

Spiering or Smelt (Struis Bay), Spieringtje

(Cape), Assance (Castelnau), Assous, voce (Hout Bay) ............... Atherina breviceps ........ 215, 224

Springer, Leaping Mullet ........... Mugil multilineatus ......... 223

Spotted Ray. Vide Rog.

Spotted Steenbras (Simonstown)....... Pristipoma operculare.

Steenbras, Steenbrasen (Castelnau), Steenbraesem (Riebeck's Journal), White Steenbras, Kaapsche Blaauwe Steenbras (Pappe), Forke Bak (Knysna)? Vark

Bek (Mossel Bay) .............. Pagellus lithognathus ..... 209, 221

Steenje .................................

Steen-klip-visch (Pappe), see also Pampelmoesje..................... Chilodactylus brachydactylus ... 224

Steen-visch (Pappe), Steen-klip-visch (Fishermen) ........................ 224

Sting Ray. Vide Pijl-staart.

Stink-fish. Vide Bamboes-visch.

Stok-visch, Stock-fish, Hake (P. Elizabeth) Merlucius vulgaris ........ 211

Stompneus, Stumpnose, White Stumpnose, Wit Stompneus ........... Chrysophrys globiceps ........ 223

Streepje. Vide Bamboo-fish.

Streep-visch. Vide Seventy-four.

Stripe-fish. Vide Seventy-four.

Stumpnose. Vide Stompneus.

Sucker-fish. Vide Klip-Zuiger.

Sunfish. Vide Maan-visch.

Sussie. Vide Sardijn.

TambriJn. Vide John Brown.

Trek Galjoen. Vide Galjoen.

Tiger-fish, or River Steenbras (E. London) $\quad$ ?
Tiger-shark. Vide Bonte Haai.

Toad-fish. Vide Blaasop.

Tong, Tong-visch, Sole ......... Synaptura, 2 sp., \& Cynoglossus capensis 212

Tornijn Haai, or Porpoise Shark (Struis

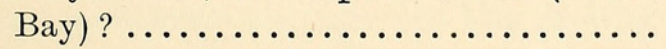

VARKJE. Vide Chor Chor.

Vark-bek. Vide Steenbras.

Vinhaai, Dog-fish Scyllium of several sp.

Vioel-visch. Vide Zand-kruiper.

Vleet. Vide Rog. 
White Bait. Vide Ansjovi.

PAGL:

White Steenbras. Vide Steenbras.

White Stumpnose. Vide Stompneus.

Wilde-paard. Zebra-fish, Five-fingers .. Sargus cervinus............ 220

Windtoy (Bleeker, Pappe, \& Castelnau),

Wind-ei, voce ................ Casio axillaris, Blgr.

Wit Kabeljaauw. Vide Kabeljaauw.

Wit Stompneus. Vide Stompneus.

Witneus Haai (Struis Bay) $\ldots \ldots \ldots \ldots$. .

Yellow-tail. Vide Albicore.

ZAND-KRUIPER, Sand-shark, Vioel-visch

(Paternoster), Fiddle-fish .......... Rhinobatus annulatus

Zebra-fish. Vide Wilde-paard.

Zee-basje. Vide Barsje.

Zee-slang ..................... Bdellostoma cirrhatum.

Zee-vark, Porcupine-fish, Globe-fish (E.

London) ................... Diodon hystrix

Zeverrim. Vide Barsje.

Zilver-visch (Kolbe), Silver-fish, Rooitje (Knysna)? Kaapenaar (Port Elizabeth),

Carpenter, Sand Silver (East London).

Vide also Seventy-four.............

Dentex argyrozona ........ 223, 224 


\section{$2 \mathrm{BHL}$ Biodiversity Heritage Library}

Gilchrist, J. D. F. 1900. "HISTORY OF THE LOCAL NAMES OF CAPE FISH." Transactions of the South African Philosophical Society 11, 207-232. https://doi.org/10.1080/21560382.1900.9525967.

View This Item Online: https://www.biodiversitylibrary.org/item/113791

DOI: https://doi.org/10.1080/21560382.1900.9525967

Permalink: https://www.biodiversitylibrary.org/partpdf/175446

\section{Holding Institution}

Field Museum of Natural History Library

\section{Sponsored by}

The Field Museum's Africa Council

\section{Copyright \& Reuse}

Copyright Status: NOT_IN_COPYRIGHT

This document was created from content at the Biodiversity Heritage Library, the world's largest open access digital library for biodiversity literature and archives. Visit BHL at https://www.biodiversitylibrary.org. 